\title{
$\frac{20}{4-1100}$
}

th. 2000

UCRL-52394

\section{AN APPARATUS FOR SIMULTANEOUSLY MEASURING ELECTRICAL CONDUCTIVITY AND OXYGEN FUGACITY}

\author{
R. Netherton \\ A. Duba
}

January 31,1978

Work performed under the auspices of the U.S. Department of Energy by the UCLLL under contract number W-7405-ENG-48.

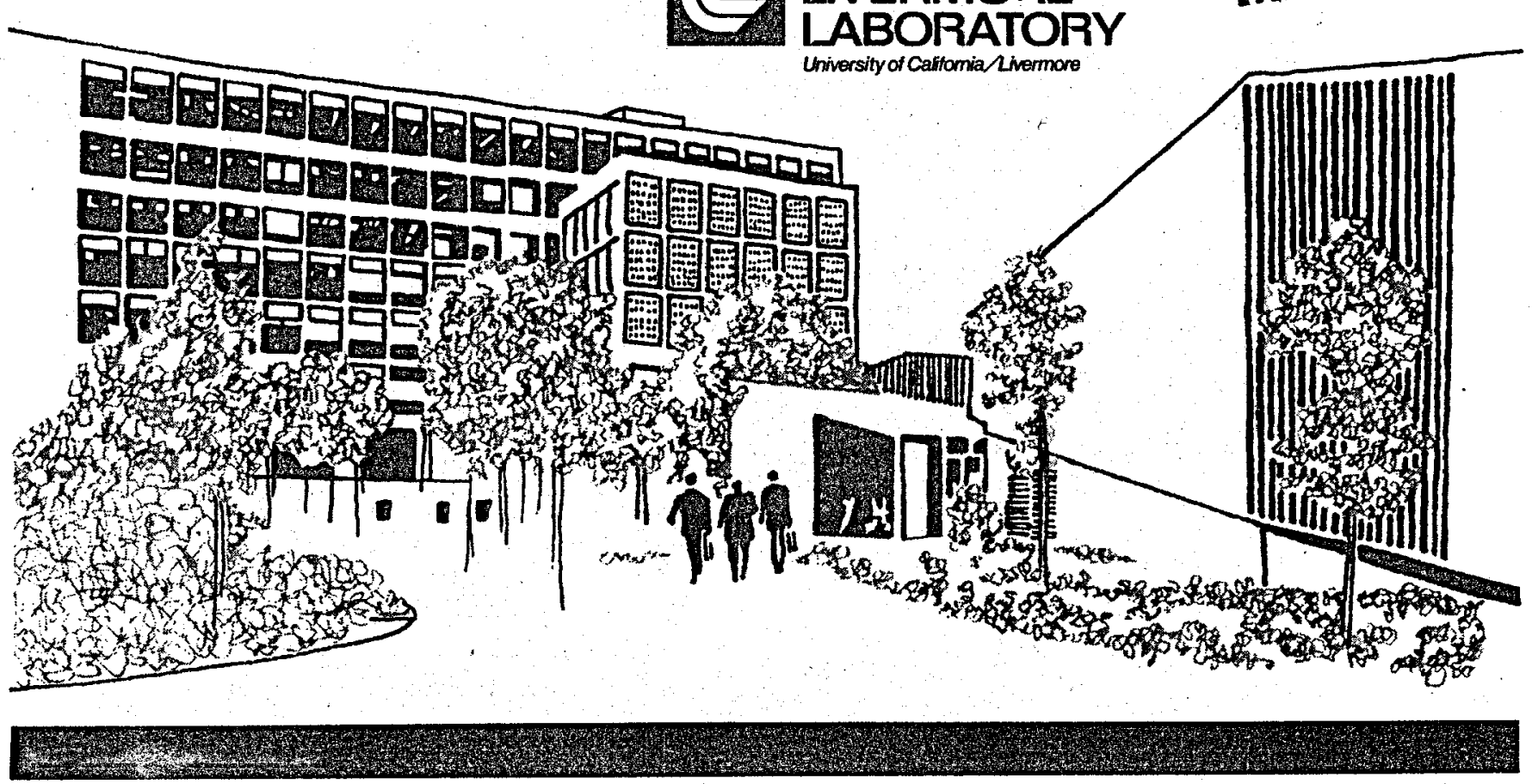




\section{DISCLAIMER}

This report was prepared as an account of work sponsored by an agency of the United States Government. Neither the United States Government nor any agency Thereof, nor any of their employees, makes any warranty, express or implied, or assumes any legal liability or responsibility for the accuracy, completeness, or usefulness of any information, apparatus, product, or process disclosed, or represents that its use would not infringe privately owned rights. Reference herein to any specific commercial product, process, or service by trade name, trademark, manufacturer, or otherwise does not necessarily constitute or imply its endorsement, recommendation, or favoring by the United States Government or any agency thereof. The views and opinions of authors expressed herein do not necessarily state or reflect those of the United States Government or any agency thereof. 


\section{DISCLAIMER}

Portions of this document may be illegible in electronic image products. Images are produced from the best available original document. 
NOTICE

"This report was prepared as an account of work aponsored by the United States Government. Neither the United States nor the United States Department of Energy, nor any of their em. ployees, nor any of their contractors, subcontractors, or their employees, makes any warranty, express or implied, or assumes any legal liabulity or responsibility for the accuracy, completeness or usefuiness of any information, apparatus, product or process disclosed, or represents that its use would not infringe privately-owned rights."

\section{NOTICE}

Reference to a company or product name does not imply approval or recommendation of the product by the University of California or the U.S. Department of Energy to the exclusion of others that may be suitable.

Printed in the United States of America Available from

National Technical Information Service

U.S. Department of Commerce

528.5 Port Royal Road

Springfield, VA 22161

Price: Printed Copy $\$$; Microfiche $\$ 3.00$

\begin{tabular}{ccccc} 
Page Range & $\begin{array}{c}\text { Domestic } \\
\text { Price }\end{array}$ & Page Range & $\begin{array}{c}\text { Domestic } \\
\text { Price }\end{array}$ \\
\cline { 4 - 5 } $001-025$ & $\$ 4.00$ & & $326-350$ & $\$ 12.00$ \\
$026-050$ & 4.50 & $351-375$ & 12.50 \\
$051-075$ & 5.25 & $376-400$ & 13.00 \\
$076-100$ & 6.00 & $401-425$ & 13.25 \\
$101-125$ & 6.50 & $426-450$ & 14.00 \\
$126-150$ & 7.25 & $451-475$ & 14.50 \\
$151-175$ & 8.00 & $476-500$ & 15.00 \\
$176-200$ & 9.00 & $501-525$ & 15.25 \\
$201-225$ & 9.25 & $526-550$ & 15.50 \\
$226-250$ & 9.50 & $551-575$ & 16.25 \\
$251-275$ & 10.75 & $576-600$ & 16.50 \\
$276-300$ & 11.00 & $601-40$ & 1 \\
$301-325$ & 11.75 & &
\end{tabular}

${ }^{1}$ Add $\$ 2.50$ for ench additional 100 naee inemement from 601 pages up. 


\section{近 \\ LAWRENCE LVERMORE LABORATORY \\ University of Cahtornia/Livermore, California/94550}

UCRL-52394

\section{AN APPARATUS FOR SIMULTANEOUSLY MEASURING ELECTRICAL CONDUCTIVITY AND OXYGEN FUGACITY}

R. Netherton
A. Duba

MS. date: January 31, 1978

\begin{tabular}{|c|}
\hline 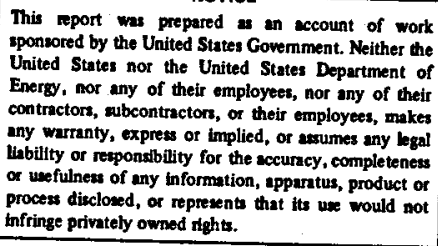 \\
\hline
\end{tabular}




\title{
AN APPARATUS FOR SIMULTANEOUSLY MEASURING ELECTRICAL CONDUCTIVITY AND OXYGEN FUGACITY
}

\begin{abstract}
Electrical conductivity studies of silicates are useful in determining temperature vs depth in the earth. Realistic laboratory measurements of conduction mechanisms require that exact determinations of oxygen fugacity $\left(f_{\mathrm{O}_{2}}\right)$ be made in the experimental environment. An apparatus is described that monitors system $f_{\mathrm{O}_{2}}$ with a calcia-doped zirconiaoxygen cell while measuring electrical conductivity of iron-bearing silicates at high temperature $(>1000 \mathrm{~K})$. The $f_{\mathrm{O}_{2}}$ calculated thermodynamically from $\mathrm{CO} / \mathrm{CO}_{2}$ mixing ratios agreed well with measurements made with the zirconia cell at $1473 \mathrm{~K}$, except for $f_{\mathrm{O}_{2}}$ $>10^{-4} \mathrm{~Pa}$, where, on a $\log _{10}$ scale, mixing-ratio errors were as large as \pm 0.2 . These errors are attributed to oxygen contamination in the $\mathrm{CO}_{2}$ and to mobile carbon deposits that formed in the apparatus.
\end{abstract}

\section{INTRODUCTION}

Electrical conductivity $(\sigma)$ of silicates has been studied extensively as a means to determine temperature vs depth in the earth. The control of oxidation

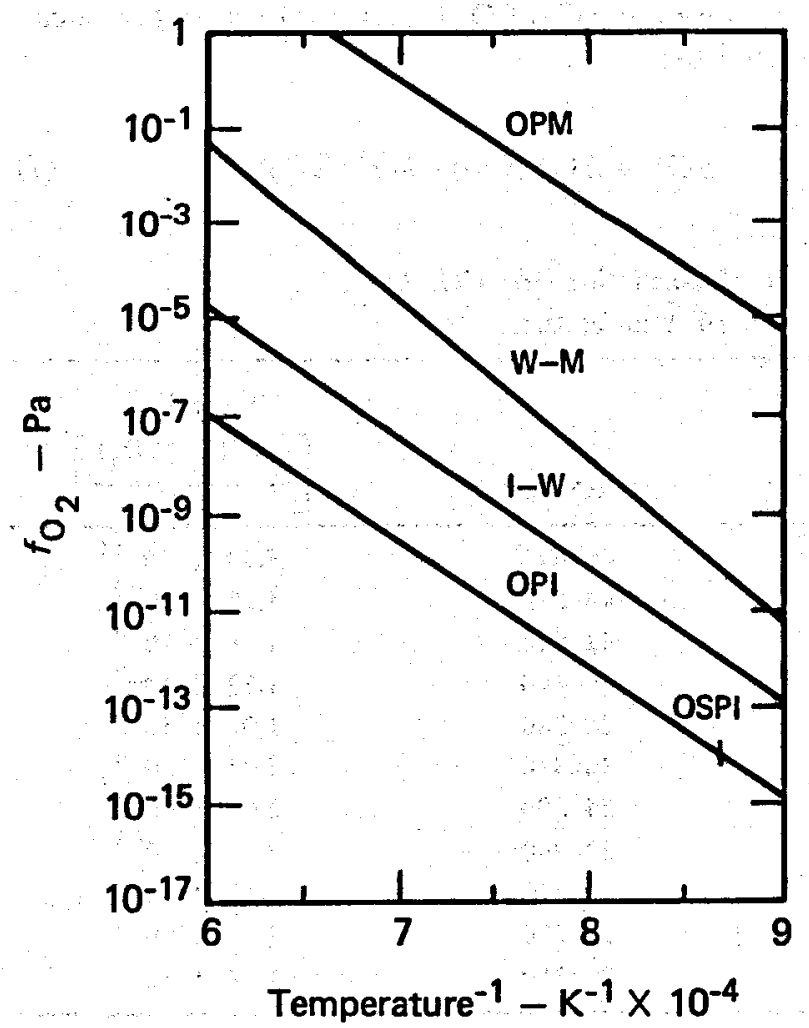

state has been shown to be essential during hightemperature measurements of the electrical conductivity of iron-bearing silicates such as olivine ${ }^{1}$ and pyroxene. ${ }^{2}$ Oxidation-state control is also necessary when measuring other material properties like optical absorption ${ }^{3}$ and high-temperature creep, ${ }^{4}$ which are sensitive to trace impurities. However, control of oxidation state alone is not always sufficient when measuring high-temperature conductivity; the oxygen fugacity $\left(\mathrm{fO}_{2}\right)$ of the experimental environment must also be known before precise interpretation of conductivity mechanisms is possible.

The oxygen fugacity with which a silicate is in equilibrium is temperature dependent. This is shown in Fig. 1, which illustrates the oxidationreduction boundaries for olivine ${ }^{5}$ containing about 9 wt\% iron $\left(\mathrm{Mg}_{1.8} \mathrm{Fe}_{0.2} \mathrm{SiO}_{4}\right)$. The iron-wüstite (I-W, $\mathrm{Fe}-\mathrm{FeO}$ ) and the wiistite-magnetite (W-M, $\mathrm{FeO}-\mathrm{Fe}_{3} \mathrm{O}_{4}$ ) boundaries ${ }^{6}$ are shown in this figure as

Fig. 1. The stability field of olivine containing $\sim 10 \%$ fayalite as a function of temperature and $\int_{\mathrm{O}_{2}}$. OPM line is the boundary above which olivine oxidizes to form pyroxene and magnetite. OPI-OSPI line is boundary below which olivine reduces to form either olivine (forsterite), pyroxene, and iron or olivine (forsterite), sillica, pyroxene, and iron, depending on temperature. The $I-W$ and $W-M$ lines are the Iron-wiistite and wistite-magnetite boundaries, respectively. 
references to the low oxygen fugacity in equilibrium with olivine. Within this broad olivine stability field, conductivity may vary up to one-half an order of magnitude as a function of oxygen fugacity. ${ }^{7}$ Controlled studies of conductivity as a function of oxygen fugacity should help us to understand the defect structure and complex conduction mechanisms in olivine and pyroxene. Such studies can also be used to interpret electromagnetic induction data from the earth ${ }^{8}$ and moon. ${ }^{9}$ In this report, we describe the design and operation of an apparatus for simultaneously measuring $\sigma$ and $f_{\mathrm{O}_{2}}$.

\section{BACKGROUND}

Gas mixers have long been used to control the $\mathrm{fO}_{2}$ of experimental atmospheres. ${ }^{10}$ The gases are assumed to be in equilibrium, and $\mathrm{fO}_{2}$ is calculated from their free energies of formation 11 as described below.

We use $\mathrm{CO}_{2}$ and $\mathrm{CO}$ for controlling $f_{\mathrm{O}_{2}}$. To calculate $\mathrm{f}_{2}$, we consider the reaction

$$
\mathrm{CO}_{2} \mathrm{CO}+1 / 2 \mathrm{O}_{2}
$$

with an equilibrium constant, ${ }^{12} \mathrm{~K}_{\mathrm{p}}$ of

$$
\mathrm{K}_{\mathrm{p}}=\frac{\left[\mathrm{P}_{\mathrm{Co}}\right]\left[\mathrm{P}_{\mathrm{O}_{2}}\right]^{1 / 2}}{\left[\mathrm{P}_{\mathrm{CO}_{2}}\right]}
$$

where $P_{i}$ is the partial pressure of the $i^{\text {th }}$ component $\left(\mathrm{i}=\mathrm{CO}, \mathrm{CO}_{2}\right.$, etc.) in the gas phase. Solving for $\mathrm{PO}_{2}$, we find that

$$
\mathbf{P}_{\mathrm{O}_{2}}=\mathrm{K}_{\mathrm{p}}^{2} \frac{\left[\mathrm{P}_{\mathrm{CO}_{2}}\right]^{2}}{\left[\mathrm{P}_{\mathrm{Co}}\right]^{2}}
$$

Because

$$
\Delta G^{\circ}=-R T \ln K_{p}
$$

and

$$
\Delta G^{\circ}=\Delta G_{f}^{\circ} \text { (products) }-\Delta G_{f}^{\circ} \text { (reactants) }
$$

then

$$
K_{p}=\exp \left(-\Delta G^{\circ} / R T\right)
$$

where $\Delta \mathbf{G}_{f}^{\circ}$ is the free energy of formation, $R$ is the gas constant, and temperature $T$ is in kelvins.

Table 1 lists $\Delta \mathrm{G}^{\circ}$ for $\mathrm{CO}$ and $\mathrm{CO}_{2}$ from $1000-2000 \mathrm{~K}$ as compiled by Coughlin. ${ }^{11}$ As required in Eq. (6), $\Delta \mathrm{G}^{\circ}$ is included in this table, and because the $\Delta G_{f}^{\circ}$ of $O_{2}$ is zero, $\Delta G^{\circ}$ is simply calcu-

\begin{tabular}{|c|c|c|c|c|}
\hline $\begin{array}{c}\text { Temperature, } \\
\mathbf{K}\end{array}$ & $-\Delta \mathbf{G}_{f}^{\circ} \mathbf{C O}$ & $-\Delta G_{f}^{\circ} \mathrm{CO}_{2}$ & $\Delta G^{\circ}\left(\mathrm{CO}-\mathrm{CO}_{2}\right)$ & {$\left[\frac{-\Delta G^{\sigma}\left(\mathrm{CO}-\mathrm{CO}_{2}\right)}{\mathrm{RT}}\right.$} \\
\hline 1000 & $47940( \pm 20)$ & $94610( \pm 30)$ & 46670 & $6.30 \times 10^{-11}$ \\
\hline 1100 & 50050 & 94640 & 44590 & $1.38 \times 10^{-9}$ \\
\hline 1200 & 52150 & 94660 & 42510 & $1.81 \times 10^{-8}$ \\
\hline 1300 & 54240 & 94680 & 40440 & $1.59 \times 10^{-7}$ \\
\hline 1400 & 56310 & 94690 & 38380 & $1.02 \times 10^{-6}$ \\
\hline 1500 & 58370 & 94710 & 36340 & $5.07 \times 10^{-6}$ \\
\hline 1600 & 60430 & 94730 & 34300 & $2.06 \times 10^{-5}$ \\
\hline 1700 & 62460 & 94720 & 32260 & $7.12 \times 10^{-5}$ \\
\hline 1800 & 64480 & 94720 & 30240 & $2.13 \times 10^{-4}$ \\
\hline 1900 & 66500 & 94720 & 28220 & $5.67 \times 10^{-4}$ \\
\hline 2000 & 68510 & 94720 & 26210 & $1.37 \times 10^{-3}$ \\
\hline
\end{tabular}
lated by:

$$
\Delta \mathrm{G}^{\circ}=\Delta \mathrm{G}_{f}^{\circ}(\mathrm{CO})-\Delta \mathrm{G}_{f}^{\circ}\left(\mathrm{CO}_{2}\right)
$$

Table 1. Free energies (cal mole ${ }^{-1}$ ) of formation for $\mathrm{CO}, \mathrm{CO}_{2}$, $\Delta G^{\circ}\left(\mathrm{CO}^{-} \mathrm{CO}_{2}\right)$, and $\mathrm{K}_{\mathrm{p}}$ as a function of temperature. 
Table 1 also includes values of $K_{p}$ calculated from Eq. (6). This value of $K_{p}$ can then be substituted in- to Eq. (2) to calculate $f_{\mathrm{O}_{2}}$ for a given gas mixture at any temperature.

\section{EXPERIMENTAL}

The gas mixer shown in Fig. 2 was constructed to control the $\mathrm{CO}_{2} / \mathrm{CO}$ ratio in our apparatus. Carbon monoxide and carbon dioxide are supplied at approximately $65 \mathrm{kPa}$ through a line filter (also serving as a surge tank) to precision regulators that supply gas at about $40 \mathrm{kPa}$ to filter-protected micrometer valves. The valves are used to regulate flow indicated by floating-ball flowmeters. The gases are then mixed and supplied to the experimental assembly, which is inside a furnace capable of reaching $2000 \mathrm{~K}$.

Figure 3 is a calibration curve for the flowmeters of the gas mixer. Calibration was made by transittime measurements of soap bubbles in either 10- or $50-\mathrm{ml}$ burettes connected to the furnace outlet. A smaller-capacity flowmeter is used for $\mathrm{CO}$ because our applications generally require less $\mathrm{CO}$ than $\mathrm{CO}_{2}$.

The dashed lines of Fig. 4 illustrate the $\mathrm{fO}_{2}$ limits achieved by the mixer in Fig. 2. These calculations were made using Eq. (6) and Table 1. For reference, the oxidation-reduction reactions of Fig. 1 are also reproduced in Fig. 4.

The $\mathrm{fO}_{2}$ of pure $\mathrm{CO}_{2}$ shown in Fig. 4 is calculated as follows. For $\mathrm{CO}_{2}$ only, $\mathrm{P} \mathrm{CO}_{2}=1$, and

$$
\left[\mathrm{P}_{\mathrm{CO}}\right]=\left[\mathrm{P}_{2}\right]^{1 / 2} \text {. }
$$

Combining Eqs. (2) and (8), we obtain

$$
\mathrm{P}_{\mathbf{2}}=\mathrm{K}_{\mathrm{p}}^{3 / 2}
$$

The calculated value of $\mathrm{fO}_{2}$ described above may not be the true $\mathrm{fo}_{2}$ in the assembly for several reasons. Contamination of the experimental atmosphere by outgassing of ceramics, carbon deposition at low $f_{\mathrm{O}_{2}}$, impure gases, failure to achieve equilibrium between the gases, and inaccurate flow measurement are possible error sources. Because of these and other sources of uncertainty as discussed by

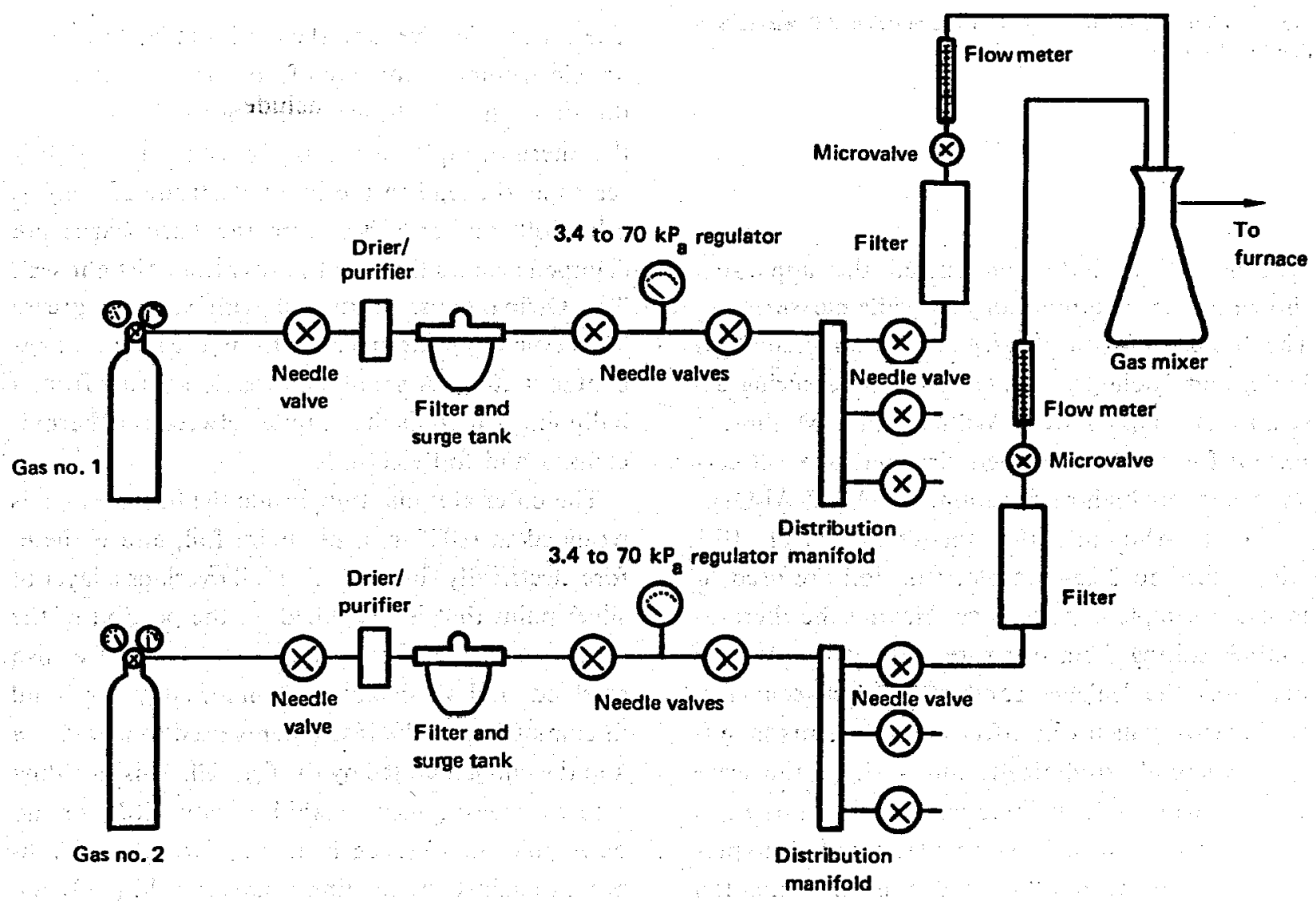

Fig. 2. Schematic diagram of the gas-mixing system. 


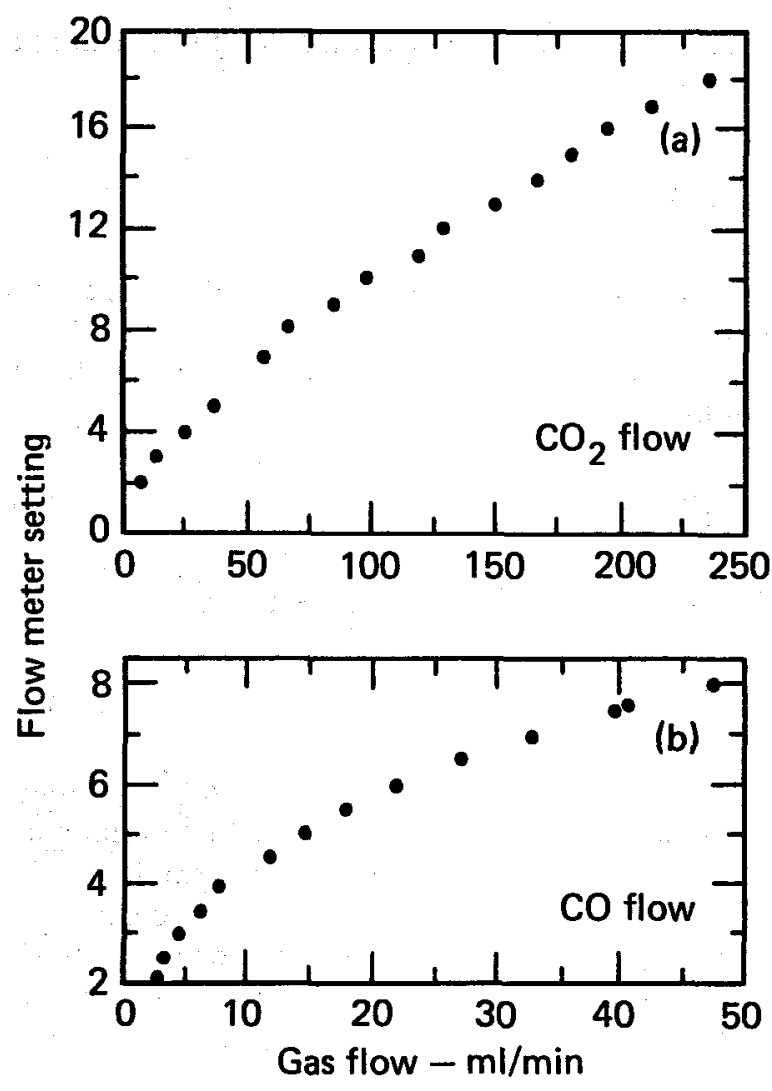

Fig. 3. Flow of (a) $\mathrm{CO}_{2}$ and (b) $\mathrm{CO}$ as a function of flowmeter setting for the gas mixer.

Huebner, ${ }^{13}$ we have constructed the apparatus shown in Fig. 5 to monitor $\mathrm{fO}_{2}$ while measuring $\sigma$. The basic $\sigma$-measuring assembly is adapted from Duba and Nicholls, ${ }^{1}$ while the $f_{\mathrm{O}_{2}}$-measuring assembly is adapted from Williams and Mullins. ${ }^{14}$ Except for the calcia-doped zirconia tube, all ceramic parts are high-purity alumina $\left(99.95 \% \mathrm{Al}_{2} \mathrm{O}_{3}\right)$.

Platinum-rhodium thermocouples (Pt-Pt $10 \%$ $\mathrm{Rh}$ ) welded to $0.25-\mathrm{mm}$ platinum foil are used to measure sample conductance. Having the thermocouples exiting from opposite ends of the furnace decreases the leakage conductance between electrode leads, which can affect measurements in systems where electrode leads emerge from the same end. ${ }^{15}$ The sample, painted with platinum paint, is sandwiched between $0.25-\mathrm{mm}$ platinum foils to prevent electrode evaporation and iron contamination of the thermocouple at temperatures $>1400 \mathrm{~K}$.

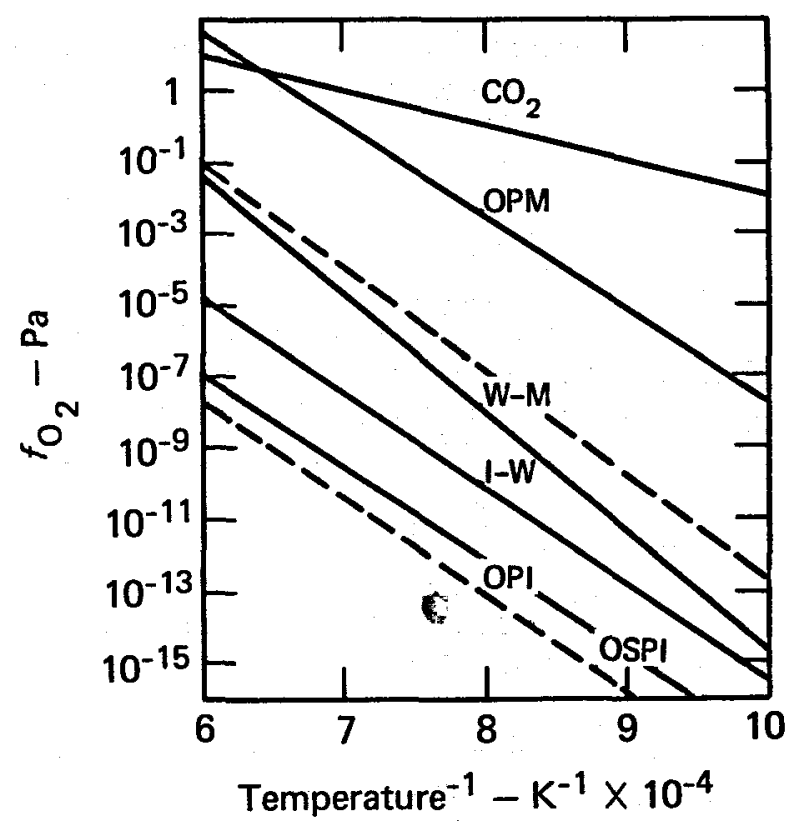

Fig. 4. The calculated limits (dashed lines) of the gas mixer in Fig. 2 compared to oxidation-reduction reactions in Fig. 1.

Thermocouple wires and the platinum lead to measure electromotive force (emf) of the $f_{\mathrm{O}_{2}}$ cell exit to the atmosphere by hose barbs. The platinum wire of the thermocouple inside the zirconia $\left(\mathrm{ZrO}_{2}\right)$ cell serves as the lead to the inner electrode of the $f_{\mathrm{O}_{2}}$ cell. Soft rubber tubes over the hose barbs are clamped around the wire to provide an airtight seal. The O-ring seals, lubricated with vacuum grease and cooled by water jackets, form a seal against gas contamination. A small compression spring from a ballpoint pen holds the sample between the thermocouples and foil electrodes.

The outer alumina tube inside the furnace area is wrapped in $0.025-\mathrm{mm}$ platinum foil, and is therefore electrically shielded. The foil overlaps a layer of silver paint that is the shield on the portion of the tube not inside the furnace. The wires are also shielded, and all shields are connected to a ground in common with the instruments used to measure $\sigma$ and the emf generated by the $f_{\mathrm{O}_{2}}$ cell. This shielding assures measurement stability with little or no detectable interference from the furnace. As calibrated against the melting point of gold $(1337 \mathrm{~K})$, temperature is measured with an accuracy of $1 \mathrm{~K}$. 

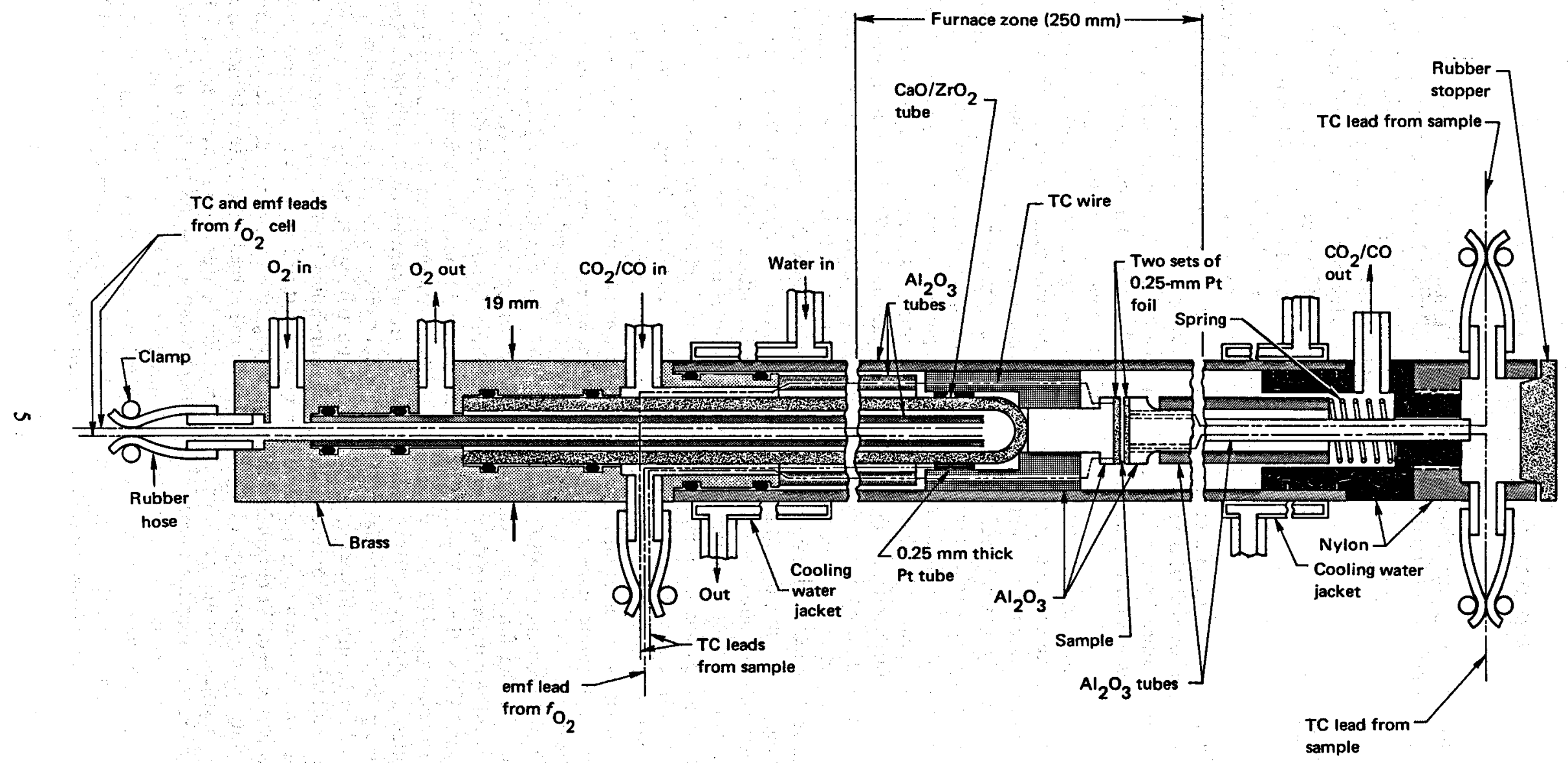

Fig. 5. Schematic of the assembly used to measure $\sigma$ and $\int_{\mathrm{O}_{2}}$. Dashed lines inside ceramic tubes indicate $\mathrm{Pt}$ or $\mathrm{Pt}-\mathrm{Rh}$ wires. 


\section{RESULTS AND DISCUSSION}

The emf generated by the zirconia-calcia $\left[\left(\mathrm{ZrO}_{2}\right)_{0.85}(\mathrm{CaO})_{0.15}\right]$ ceramic is a function of oxygen fugacity 14 :

$$
\log f_{\mathrm{O}_{2}}=-\frac{20.159}{\mathrm{~T}} \mathrm{E},
$$

where $\mathrm{E}$ is the emf in $\mathrm{mV}$. Using Eq. (10), the emf measurement system was checked against the air $/ \mathrm{O}_{2}$ cell as a function of temperature from $\sim 1075$ to $1725 \mathrm{~K}$. Figure 6 shows the results for two separate measurements.

The comparison of $\mathrm{fO}_{2}$ for air, calculated vs measured, is affected by prior adjustments of the assembly. Measurements of $\mathrm{fO}_{2}$ for air were initiated at about $1700 \mathrm{~K}$ in an assembly that previously had pure $\mathrm{CO}$ flowing at about $1600 \mathrm{~K}$, to check that the cell would generate more than $1 \mathrm{~V}$ with $\mathrm{O}_{2}$ as the reference gas. This caused some carbon to deposit in the cooler portion of the furnace (see Fig. 1 of Ref. 6). Air was then purged through the system and the temperature increased to bake out the deposited carbon. Because the maximum temperature of $1707 \mathrm{~K}$ was maintained for slightly more than one hour before the emf was measured, we assumed that the carbon deposit was not completely removed. This was confirmed by the initial high emf reading of the cell at $1707 \mathrm{~K}$ and the good agreement between calculated and measured emf at lower temperatures where carbon contamination is small because of the previous high-temperature event that outgassed deposited carbon.

Carbon deposition is a problem for all low- $\mathrm{fO}_{2}$ mixtures, as indicated by the following example. After an $\mathrm{fO}_{2}$ of $10^{-12}$ was maintained in the assembly for several hours at $1473 \mathrm{~K}$, the air $/ \mathrm{O}_{2}$ cell emf was measured both on heating to $1725 \mathrm{~K}$ and cooling. These data, plotted as squares in Fig. 6, indicate that all emf valves generated upon initial heating are high by as much as $1.3 \mathrm{mV}$. However, at the highest temperature maintained for only $20 \mathrm{~min}$ prior to measurement, and upon cooling, measured and calculated emf values agreed. We conclude that the $\mathrm{fO}_{2}$ (and presumably the composition) of a gas circulated in an experimental assembly, is affected by that assembly. Before accepting the thermodynamically calculated $f_{\mathrm{O}_{2}}$ as the true $\mathrm{fo}_{2}$, the assembly must be equilibrated with the gas mixture at a temperature greater than that at which the $\mathrm{fO}_{2}$ is to be calculated. If we use only data from the cooling cycles in Fig. 6, the measured emf is within $0.5 \mathrm{mV}$ of the calculated emf at temperatures between 1250 and $1700 \mathrm{~K}$. However, below $1250 \mathrm{~K}$, the measured emf is too low, which is consistent with the observations of Huebner ${ }^{13}$ who found that achieving equilibrium is difficult between the gases at low temperatures. The equilibrium problem is compounded because, in our furnace, we use large temperature gradients to reduce conductance-measurement errors caused by conduction in the alumina tubes.

We conclude that our system has an accuracy of at least $0.5 \mathrm{mV}$ from 1250 to $1700 \mathrm{~K}$. The error of calculating $\mathrm{fO}_{2}$ will be greatest $(<1.5 \%)$ for air where the emf generated by the cell is low, and will become insignificant $(\leqslant 0.2 \%)$ for the $f_{\mathrm{O}_{2}}$ routinely used that will generate greater than $300 \mathrm{mV}$.

To compare the $\mathrm{fO}_{2}$ calculated from the $\mathrm{CO}_{2} / \mathrm{CO}$ ratio using measured emf and Eq. (10), we first consider the special situation where only $\mathrm{CO}_{2}$ is flowing in the gas mixer. Because large gas volumes are used for continuous operation of three furnaces, expensive, high-purity $\mathrm{CO}_{2}$ is not used, and Fig. 7 shows that $\mathrm{fO}_{2}$ measurements at $1473 \mathrm{~K}$ with the zirconia are higher than that calculated from Eq. (9), which assumes pure $\mathrm{CO}_{2}$. This difference in $\mathrm{fO}_{2}$ should diminish as $\mathrm{CO}$ is added to the gas mixture because of the reaction, $\mathrm{CO}+1 / 2 \mathrm{O}_{2} \leftrightarrows \mathrm{CO}_{2} .2$ The carbon-contamination problem discussed above is evident in Fig. 7 also because $f \mathrm{O}_{2}$ 's calculated from the data collected during the cooling cycle are higher than the $\mathrm{fO}_{2}$ values calculated from the heating cycle. The previous gas mixtures flowing in the system were at $f \mathrm{O}_{2}$ ranging from $10^{-5}$ to $10^{-8} \mathrm{~Pa}$ at $1473 \mathrm{~K}$ for several days.

In Fig. 8 is compared the $\mathrm{O}_{2}$ calculated from emf measured by the zirconia cell and that calculated from the $\mathrm{CO}_{2} / \mathrm{CO}$ ratio. All measurements were made at $1473 \mathrm{~K}$ progressing from oxidizing to reducing atmospheres to introduce the minimum error from carbon contamination. However, the previous mixture in the system had been $<10^{-6} \mathrm{~Pa}$ and no baking out at high temperature $(1473 \mathrm{~K})$ was attempted; therefore, the error is that expected in the worst situation. The data should be at the 1:1 line (Fig. 8) if the $\mathrm{fO}_{2}$ values calculated from the zirconia cell agreed with those calculated from the gas mixture. Mixtures more oxidizing than $10^{-4} \mathrm{~Pa}$ at $1473 \mathrm{~K}$ fall above the $1: 1$ line, indicating the error introduced by the contamination of carbon produced by outgassing as indicated in Figs. 6 and 7. In more reducing $\mathrm{fO}_{2}$ atmospheres, the $1: 1$ line is followed more closely. 


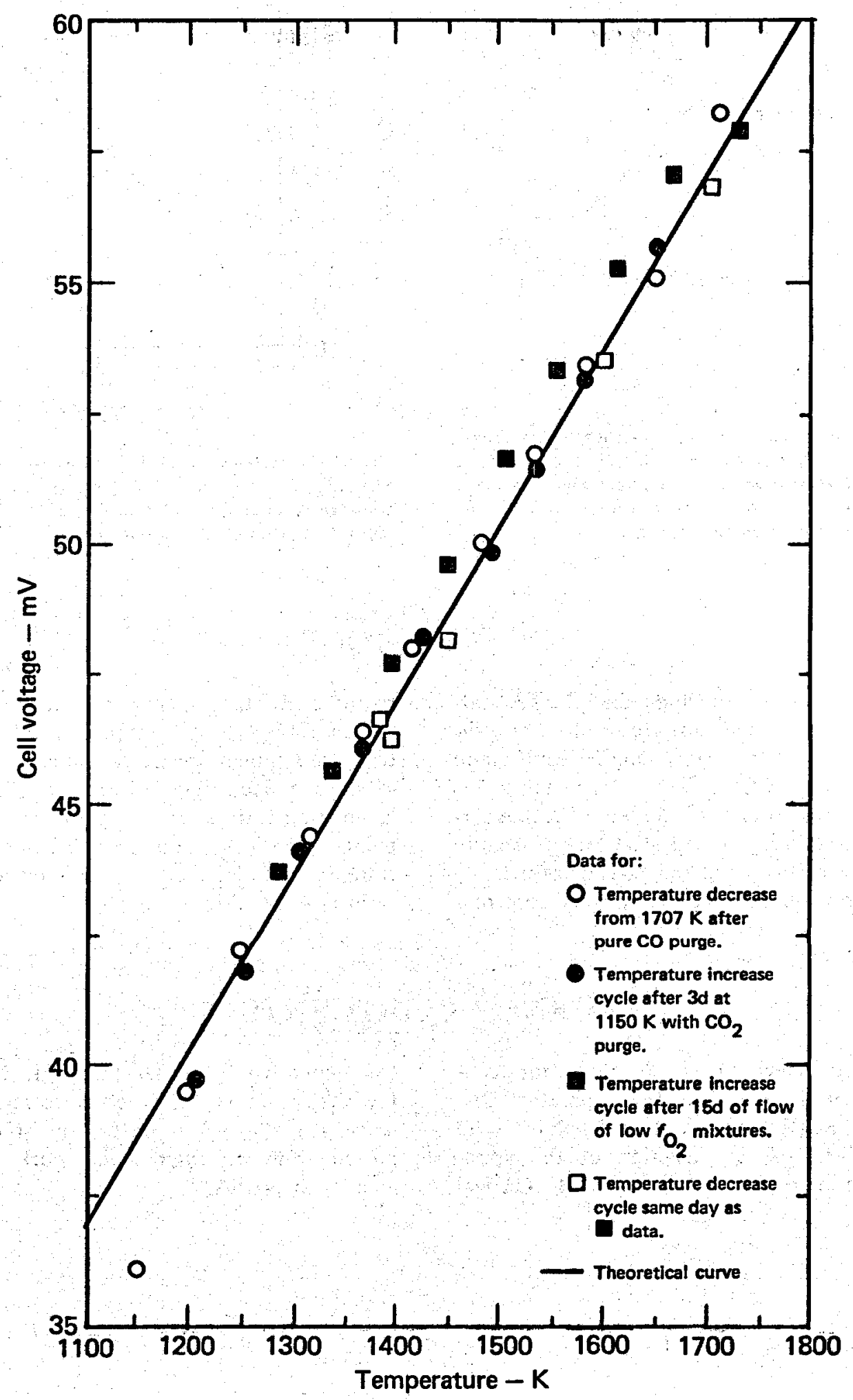

Fig. 6. Voltage generated by the air $/ \mathrm{O}_{2}$ cell vs temperature. Solid line is the calculated emf for air using Eq. (10). 


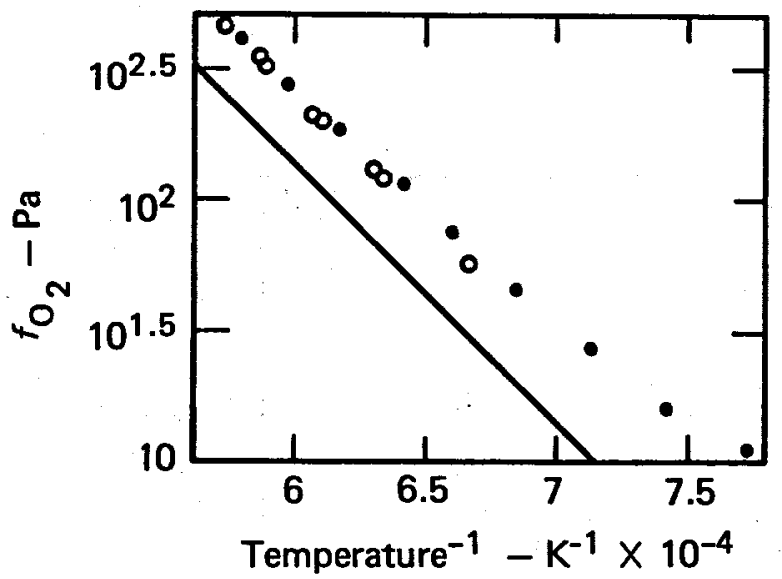

Fig. 7. The oxygen fugacity of $\mathrm{CO}_{2}$ as a function of temperature. Line is calculated using Eq. (9), open circles are calculated from oxygen cell measurements made on temperature-increase cycle, closed circles are calculated from measurements made on temperaturedecrease cycle on the same day.

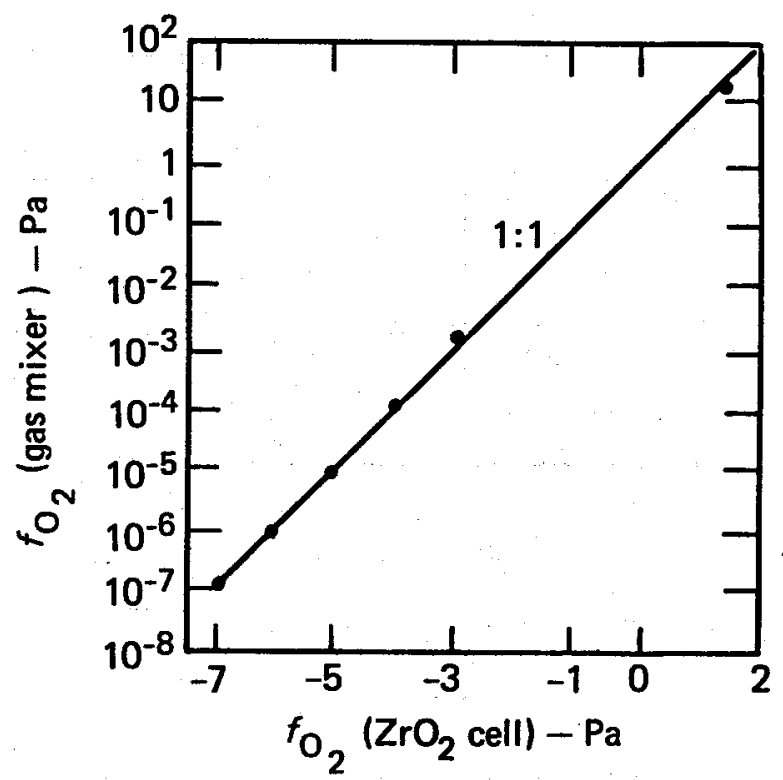

Fig. 8. Oxygen fugacity (circles) calculated from the gas-mixing data using Eq. (2) compared to those calculated from the emf measured by the uirconia cell. Solid line indicates a slope of $1: 1$ in which the two calculations would agree.

\section{CONCLUSIONS}

From this study we conclude that the $f_{\mathrm{O}_{2}}$ calculated from gas mixing ratios are accurate to within $\sim 0.2$ of a $\log _{10}$ unit at $f_{\mathrm{O}_{2}}$ ranging from air to that of a mixture $\left(\mathrm{CO}_{2} / \mathrm{CO}=9.75\right)$ yielding $\mathrm{fO}_{2}$ $\cong 10^{-3} \mathrm{~Pa}$. Care should be taken, however, that carbon contamination is avoided. The best procedure is to bake out the system at higher temperatures before making measurements if accurate $\mathrm{fO}_{2}$ control is required. Because of these problems with contamination, if the $\mathrm{fO}_{2}$ of the experimental atmosphere is to be determined precisely, it must be measured by an oxygen electrolyte cell and not calculated from gas-mixing ratios. However, for routine measurements where $f \mathrm{O}_{2}$ accuracy of 0.2 of a $\log _{10}$ unit is suitable, the calculated $f_{\mathrm{O}_{2}}$ based on the gas mixing ratio is acceptable.

\section{ACKNOWLEDGMENTS}

We thank R.Brotzman and E. Lilley for technical help in initial design of the apparatus. Discussion with $\mathbf{R}$. Williams and $S$. Huebner were most helpful in the construction of the apparatus and the interpretation of the results. Critical comments from W. Durham, H. Heard, A. J. Piwinskii, and H. C. Weed were most helpful in revising the original draft. This study was supported from an interagency work order agreement with NASA. 


\section{REFERENCES}

1. A. Duba and I. A. Nicholls, "The Influence of Oxidation State on the Electrical Conductivity of Olivine," Earth Planet. Sci. Lett. 18, 59 (1973).

2. A. Duba, J. N. Boland, and A. E. Ringwood, "Electrical Conductivity of Pyroxene," J. Geol. 81, 727 (1973).

3. T. J. Shankland, U. Nitsan, and A. Duba, "Optical Absorption and Radiative Heat Transport in Olivine at High Temperature," J. Geophys. Res., in press, 1978.

4. D. L. Kohlstedt and C. Goetze, "Low-Stress High-Temperature Creep in Olivine Single Crystals," J. Geophys. Res. 79, 2045 (1974).

5. U. Nitsan, "Stability Field of Olivine with Respect to Oxidation and Reduction," J. Geophys. Res. 79, 706 (1974).

6. P. Deines, R. H. Nafziger, G. C. Ulmer, and E. Woermann, "Temperature-Oxygen Fugacity Tables for Selected Gas Mixtures in the System C-H-O at One Atmosphere Total Pressure," Bull. Earth and Mineral Sciences Experimental Station, Penn. State Univ. 88 (1974).

7. A. Duba, A Review of the Relevance of Laboratory Electrical Conductivity Data to the Earth, Lawrence Livermore Laboratory, Rept. UCRL-78275 (1975).

8. R. J. Banks, "The Overall Conductivity Distribution of the Earth," J. Geomag. Geoelect. 24, 337 (1972).

9. C. P. Sonett, B. F. Smith, D. S. Colburn, G. Schubert, and K. Schwartz, "The Induced Magnetic Field of the Moon: Conductivity Profiles and Inferred Temperature," Proc. Lunar Sci. Conf. 3rd, 2309 (1972).

10. L. S. Darken and R. W. Gurry, "The System Iron-Oxygen. I. The Wuistite Field and Related Equilibria," J. Amer. Chem. Soc. 67, 1398 (1945).

11. J. P. Coughlin, "Contributions to the Data on Theoretical Metallurgy. XII. Heats and Free Energies of Formation of Inorganic Oxides," U.S. Bureau of Mines Bull 542 (1954).

12. W. J. Moore, "Thermodynamics and Chemical Equilibrium," in Physical Chemistry, Third Edition (Prentice-Hall, Englewood Cliffs, N.J., 1962), Ch. 6.

13. J. S. Huebner, "Oxygen Fugacity Values of Furnace Gas Mixtures," Am. Mineralogist 60, 815 (1975).

14. R. J. Williams and O. Mullins, A System Using Solid Ceramic Oxygen Electrolyte Cells to Measure Oxygen Fugacities in Gas-Mixing Systems, National Aeronautics and Space Administration, Houston, Rept. NASA TM X-58167, JSC-09909 (1976).

15. P. K. Larsen and R. Metselaar, "Electrical Properties of Yttrium Iron Garnet at High Temperatures, Phys. Rev. B 14, 2520 (1976). 